\title{
ANALISIS CLUSTER PERSEPSI KONSUMEN TERHADAP PRODUK HANDPHONE UNTUK MENENTUKAN STRATEGI PROMOSI PENJUALAN di ZICOMS
}

\author{
Lilia Arum Suryanita ${ }^{(1)}$,Permadina Kanah Arieska ${ }^{(2)}$ \\ ${ }^{(1),(2)}$ F.MIPA Universitas PGRI Adi Buana Surabaya
}

\begin{abstract}
ABSTRAK
Handphone adalah salah satu perkembangan alat komunikasi dan perangkat telekomunikasi elektronik yang dapat dibawa ke mana-mana serta tidak perlu disambungkan dengan jaringan telepon menggunakan kabel. Penelitian ini bertujuan untuk mengetahui langkah-langkah analisis cluster dengan metode Complete Linkage serta mengelompokkan persepsi konsumen terhadap produk handphone dalam menentukan strategi promosi penjualan di toko Zicoms.

Langkah-langkah analisis cluster menggunakan metode Complete Linkage yaitu diawali dengan mencari dua obyek terdekat dan keduanya membentuk cluster yang pertama. Langkah selanjutnya yaitu menghitung jarak terjauh antara cluster pertama yang telah terbentuk dengan obyek lainnya, dengan demikian terbentuk matriks jarak yang baru. Proses ini akan berlanjut sampai akhirnya terbentuk cluster tunggal.

Hasil dari pengelompokkan tersebut terbentuk 4 cluster dengan cluster 1 berjumlah 9 responden, cluster 2 berjumlah 21 responden, cluster 3 berjumlah 6 responden, dan cluster 4 berjumlah 4 responden. Berdasarkan hasil pengelompokkan tersebut, dengan jumlah responden terbanyak terletak pada cluster 2 maka saran promosi diprioritaskan terhadap cluster 2.
\end{abstract}

Kata kunci : Handphone, Analisis Cluster, Complete Linkage

\begin{abstract}
Mobile phone is one of the developments of communication tools and electronic telecommunication devices that can be taken anywhere and do not need to be connected to the telephone network using a cable. This study aims to determine the cluster analysis steps which use Complete Linkage method and also classify consumer perceptions of mobile phone product in determining the sales promotion strategy in electronic shop, Zicoms.

The steps of cluster analysis using Complete Linkage method are started with searching for the two nearest objects and both form the first cluster. The next step is to calculate the farthest distance between the first clusters that have been formed with other objects so that a new distance matrix forms. This process will continue until a single cluster finally forms.

The results of the grouping formed four clusters. They are cluster 1 consisting of 9 respondents, cluster 2 consisting of 21 respondents, cluster 3 consisting of 6 respondents, and cluster 4 consisting of 4 respondents. Based on the results of the grouping, the largest number of respondents lies on cluster 2 so that the prioritized promotion advices to cluster 2 .
\end{abstract}

Keywords; Mobile Phone, Cluster Analysis, Complete Linkage

\section{PENDAHULUAN}

Perkembangan teknologi komunikasi berkembang begitu pesat, yang tidak lepas dari pengaruh arus globalisasi dunia. Surat dan telegram merupakan alat komunikasi yang dipakai oleh orang dahulu untuk mendapatkan informasi dari orang lain yang berada jauh darinya. Handphone merupakan salah satu perkembangan alat komunikasi dan perangkat telekomunikasi elektronik yang dapat dibawa ke mana- mana serta tidak perlu disambungkan dengan jaringan telepon menggunakan kabel.

Pada awalnya alat komunikasi handphone ini hanya digunakan oleh kalangan tertentu yang mampu membelinya, karena harganya yang sangat mahal. Namun kini, dapat kita jumpai dengan mudah orangorang yang mempunyai handphone, bahkan saat ini telah tersedia handphone yang dilengkapi internet dengan berbagai bentuk dan merek dari yang paling murah sampai yang paling mahal. 
Tidak jauh berbeda dengan perkembangan handphone dari masa ke masa yang semakin canggih. Perkembangan trend komputer pun yang berukuran besar, semakin hari semakin kecil dan ringan. Jika tahun 80-an tren komputer masih dikuasai oleh komputer pribadi dengan CPU dan monitor yang berukuran besar. Maka pada tahun 1981 laptop atau komputer jinjing sudah mulai menjadi tren dengan nama Osborne 1, tetapi keberadaan notebook (laptop dengan ukuran yang lebih kecil) baru booming sekitar tahun 2000-an, komputer dengan CPU dan monitornya yang besar berganti dengan laptop dengan ukuran yang lebih ringan dan bisa dijinjing kemana-mana.

Belakangan ini kebutuhan akan gadget semakin meningkat, gadget tidak hanya difungsikan sebagai alat komunikasi, namun juga untuk mendukung pekerjaan serta memenuhi kebutuhan terhadap informasi dan hiburan. Tidak heran hampir semua orang tidak bisa lepas dari barang yang satu ini.Sampai hari ini produkproduk gadget masih dianggap sebagai salah satu barang elektronik yang cukup mewah di kalangan masyarakat. Sehingga wajar adanya bila sebagian besar penggemar barang gadget adalah masyarakat kelas menengah atas serta kalangan anak muda yang senang mengikuti perkembangan teknologi modern saat ini.

Seiring dengan perkembangan teknologi dan perubahan gaya hidup yang semakin modern, kedepannya tingkat kebutuhan masyarakat akan produk-produk gadget seperti smartphone dan komputer tablet diperkirakan akan mengalami lonjakan yang semakin pesat. Apalagi sekarang ini inovasi-inovasi produk gadget terbaru terus bermunculan dengan menawarkan beragam teknologi canggih bagi para calon konsumen, sehingga tidak heran bila daya tarik produk gadget semakin tinggi dan prospek pasarnya semakin hari kian terbuka lebar.

Berbagai macam merek gadget pun menguasai pasar, mulai dari harga ratusan ribu sampai jutaan rupiah pun tersedia. Seperti halnya jual beli gadgetdi toko Zicom'es yang terletak di daerah Sepanjang, Kecamatan Taman, Kabupaten Sidoarjo ini, walaupun di daerah sekelilingnya sudah terdapat banyak kompetitor yang telah lama berdiri akan tetapi tidak mengurangi tingkat penjualan gadget di Zicom ses ini.

Diawal tahun 2015 ini Zicoms melakukan penjualan gadget dengan jumlah yang besar. Penjualan gadget pada toko Zicoms didominasi oleh penjualan handphone sebesar $80 \%$ atau sekitar 450 buah handphone. Penjualan handphone ini terjadi selama bulan Januari 2015. Sedangkan untuk komputer tablet mendominasi sebesar $17 \%$ atau sekitar 93 buah tablet yang terjual. Berbeda dengan penjualan laptop, mendominasi sekitar 3\% atau sekitar 15 buah laptop yang terjual.

Penjualan handphone yang sangat besar di toko Zicoms ini, memiliki kontribusi terhadap keuntungan yang besar pula. Perlu dilakukan tindakan lebih lanjut untuk mengelompokkan produk berdasarkan variabel variabel yang menjadi kebutuhan konsumen. Hal ini diperlukan sebagai pijakan dalammelakukan promosi dan pengembangan usaha ke depan. Oleh karena itu, penelitian terkait variabel - variabel yang menunjang pengembangan usaha ke depan penting dilakukan..

\section{METODE PENELITIAN}

\subsection{Populasi dan Sampel}

Menurut Sugiyono (2013;61) populasi adalah wilayah generalisasi yang terdiri atas obyek/subyek yang mempunyai kualitas/karakteristik tertentu yang ditetapkan oleh peneliti untuk dipelajari dan kemudian ditarik kesimpulannya. Dan teknik sampling pada dasarnya dapat dikelompokkan menjadi dua yaitu Probability Sampling dan Non-Probability Sampling (Sugiyono .2013;62). Pada penelitian ini pengumpulan data dilakukan dengan menggunakan kuesioner yang terbatas pada konsumen yang membeli produk handphone di toko Zicoms daerah Sepanjang Kecamatan Taman Kabupaten Sidoarjo. Sehingga unit populasinya adalah semua konsumen yang membeli produk handphone di toko Zicoms pada bulan Februari yang berjumlah 450 orang. Sugiyono (2009:116) dengan mempertimbangkan waktu dan biaya penelitian serta kondisi populasi yang tidak mempunyai kesempatan yang sama untuk terpilih menjadi sampel, maka peneliti menggunakan metode pemilihan sampel non probabilitas. Metode pemilihan sampel non probabilitas diperoleh dari rumus Slovin (Wiratna S. \& Poly E., 2012)

\subsection{Variabel dan Definisi Operasional Variabel}

Variabel-variabel yang digunakan dalam penelitian ini dapat didefinisikan sebagai berikut :

a. Variabel Profil

Profil yang dimaksud dalam penelitian ini adalah untuk mengetahui profil dari responden meliputi :

1. Jenis Kelamin

2. Usia

3. Pekerjaan

4. Alamat

5. Pengalaman Membeli

b. Variabel Harga (X1), yaitu:

1. Pertimbangan harga saat membeli handphone (X1.1)

2.Kisaran harga handphone yang diinginkan responden (X1.2)

3. Cara pembayaran yang diinginkan responden (X1.3) c. Variabel Merek (X2)

Merek yang dimaksud dalam penelitian ini adalah :

1. Pertimbangan merek saat membeli handphone (X2.1)

2. Merek yang diminati responden di toko Zicoms (X2.2)

3. Alasan memilih merek tersebut (X2.3)

4. Merek tersebut mempunyai harga terjangkau (X2.4)

5. Merek tersebut dapat memenuhi kebutuhan (X2.5) 
d. Variabel Kualitas (X3)

Kualitas yang dimaksud dalam penelitian ini adalah

1.Pertimbangan kualitas saat membeli handphone (X3.1)

2.Kualitas suara yang diinginkan pada sebuah handphone (X3.2)

3.Kualitas kamera yang diinginkan pada sebuah handphone (X3.3)

4. Daya tahan baterai handphone yang diinginkan (X3.4)

5.Persepsi kualitas sebuah handphone menurut responden (X3.5)

6.Kualitas layar yang diinginkan pada sebuah handphone (X3.6)

e. Variabel Desain (X4)

Desain yang dimaksud dalam penelitian ini adalah :

1. Pertimbangan desain saat membeli handphone (X4.1)

2. Desain handphone yang diinginkan responden (X4.2)

3. Desain tombol handphone yang diinginkan (X4.3)

f. Variabel Manfaat (X5)

Manfaat yang dimaksud dalam penelitian ini :

1.Pertimbangan manfaat yang dimiliki saat membeli handphone (X5.1)

2.Manfaat yang diinginkan dari sebuah handphone (X5.2)

g. Variabel Garansi (X6)

Garansi yang dimaksud dalam penelitian ini :

1.Pertimbangan garansi yang dimiliki saat membeli handphone (X6.1)

2.Lama garansi yang dimiliki handphone menurut responden (X6.2)

h. Variabel Bonus (X7)

Bonus yang dimaksud dalam penelitian ini adalah :

1.Pertimbangan bonus yang didapat saat membeli handphone (X7.1)

2.Bonus yang ingin didapatkan responden saat membeli handphone (X7.2)

i. Variabel Pengalaman Pemakaian (X8)

Pengalaman pemakaian yang dimaksud dalam penelitian ini :

1. Merek yang dibeli sama atau tidak dengan merek yang sebelumnya (X8.1)

2. Jika ya, alasan membeli kembali merek tersebut (X8.2)

j. Variabel Variasi (X9)

Variasi yang dimaksud dalam penelitian ini adalah :

1.Variasi produk yang dimiliki Zicoms sudah lengkap atau belum (X9.1)

2.Penambahan yang perlu dilakukan oleh Zicoms menurut responden(X9.2)

k. Variabel Promosi (X10)

Promosi yang dimaksud dalam penelitian ini adalah :
1.Pernah atau tidak mendapatkan promosi dari toko Zicoms (X10.1)

2. Karena promosi tersebut akhirnya membeli produk di toko Zicoms(X10.2)

3. Promosi yang diinginkan responden dari toko Zicoms (X10.3)

\subsection{Metode Pengumpulan Data dan Instrumen}

Menurut Sugiyono (2002) metode pengumpulan data yang umum digunakan dalam suatu penelitian adalah wawancara, kuesioner, dan observasi. Sedangkan metode untuk pengumpulan data dari penelitian ini ditempuh dengan cara observasi atau pengamatan langsung yaitu kegiatan pengumpulan data dengan melakukan penelitian langsung terhadap kondisi lingkungan objek penelitian, sehingga didapat gambaran secara jelas tentang kondisi objek penelitian tersebut.

Pengumpulan data yang dilakukan dalam penelitian ini adalah:

\section{a. Wawancara}

Yaitu pengumpulan data dengan melakukan tanya jawab secara langsung tentang masalah yang terkait dengan penelitian, terutama data mengenai penjualan handphone di Zicoms.

b. Observasi

Observasi dilakukan dengan cara melakukan pengamatan dan pencatatan langsung terhadap objek atau hal - hal yang mempunyai keterkaitan dengan karakteristik konsumen terhadap pembelian suatu produk handphone di Zicoms.

c. Kuesioner

Dilakukan dengan cara memberikan beberapa daftar pertanyaan tertulis yang ditujukan kepada konsumen Zicoms.

d. Studi Kepustakaan

Yaitu penelitian yang dilakukan untuk memperoleh data dan informasi yang akan digunakan sebagai referensi sebagai landasan teori, sistematika penulisan, dan kerangka berfikir alamiah yang diambil dari literatur serta laporan - laporan sebelumnya yang mendukung.

\subsection{Langkah - langkah penelitian}

Langkah - langkah penelitian ini adalah:

1. Observasi Awal

2. Perumusan Masalah dan Penetapan Tujuan

3. Pengumpulan Data

a. Data Primer : Wawancara, Survey, Kuesioner

b. Data Sekunder : Data penjualan Zicoms

4. Deskriptif Profil Konsumen Zicoms

5. Asumsi Analisis Cluster

6. Pengolahan data : Analisis Klaster

7. Pembahasan

8. Kesimpulan dan Saran

\section{HASIL DAN PEMBAHASAN}


Dari total 43 kuesioner yang diisi, 3 kuesioner dianggap tidak valid (tidak diisi dengan lengkap) sehingga tersisa 40 kuesioner yang akan diproses untuk analisa selanjutnya. Setiap kuesioner berisikan dengan 11 point pertanyaan dan setiap point terdiri dari $2-6$ bulir pertanyaan. Setelah data kuesioner diolah secara analisis deskriptif, dan hasilnya banyak responden yang memilih jawaban lainnya akan tetapi tidak menyebutkan alasannya jadi hanya 15 variabel yang akan dapat menuju langkah selanjutnya yaitu memenuhi asumsi analisis cluster dengan menggunakan analisis cluster, hasil dari analisis cluster uji KMO memenuhi persyaratan karena memiliki nilai di atas 0,5 yang artinya jumlah sampel data representatif atau dapat dikatakan jumlah sampel yang diambil benar-benar bisa mewakili populasi yang ada. Dari 15 variabel hanya 8 variabel yang mempunyai nilai korelasi di atas 0,5 sehingga hanya 8 variabel yang dapat digunakan untuk pengujian selanjutnya (uji multikolinearitas)

Hasilnya dapat dilihat dari table 1 berikut:

Tabel 1. Uji multikolinearitas

\begin{tabular}{|c|c|c|}
\hline No. & Variabel & VIF \\
\hline 1 & Pengalaman Membeli & 1,134 \\
\hline 2 & $\mathrm{X}_{1.2}$ & 1,109 \\
\hline 3 & $\mathrm{X}_{1.3}$ & 1,088 \\
\hline 4 & $\mathrm{X}_{2.3}$ & 1,044 \\
\hline 5 & $\mathrm{X}_{3.4}$ & 1,222 \\
\hline 6 & $\mathrm{X}_{3.5}$ & 1,227 \\
\hline 7 & $\mathrm{X}_{5.2}$ & 1,136 \\
\hline 8 & $\mathrm{X}_{7.2}$ & 1,054 \\
\hline
\end{tabular}

Karena nilai VIF semua variabel < 10, dapat disimpulkan bahwa 8 variabel tersebut tidak terjadi multikolinearitas

Berdasarkan uji KMO dan uji multikolinearitas yang telah dilakukan maka asumsi analisis cluster telah terpenuhi. Sehingga di lakukan langkah selanjutnya yaitu menganalisis 8 variabel tersebut menggunakan analisis cluster, dan dihasilkan:

Cluster 1 terbentuk karena mempunyai sifat menyerupai antara satu sama lain dalam 8 variabel dengan jumlah responden sebanyak 9 orang yaitu Cluster 1 adalah kategori konsumen yang telah menjadi pelanggan dimana $67 \%$ dari total responden cluster 1 sebelumnya pernah berbelanja di toko Zicoms serta kategori konsumen kalangan menengah yang menginginkan kisaran harga handphone mulai dari $\mathrm{Rp} 500.000,-$ s/d $\mathrm{Rp}$ 1.000.000,-. Cluster 2 terdiri dari 21 responden dengan lebih banyak responden yang belum pernah berbelanja di toko Zicoms dimana $67 \%$ total responden cluster 2 belum pernah berbelanja di toko
Zicoms serta termasuk dalam kategori konsumen kalangan menengah karena $38 \%$ responden menginginkan handphone dengan kisaran harga mulai dari Rp 500.000,- s/d Rp 1.000.000,-. Cluster 3 terdiri dari 6 responden dan cluster 3 adalah kategori konsumen yang sudah menjadi pelanggan dan kalangan ke atas. Karena $67 \%$ dari total responden cluster 3 sebelumnya pernah berbelanja di toko Zicoms serta menginginkan kisaran harga handphone di atas Rp 2.000.000,-. Cluster 4 terdiri dari 4 responden dan cluster 4 adalah kategori konsumen yang $100 \%$ konsumen baru dan konsumen kalangan menengah dan atas karena $50 \%$ responden menginginkan handphone mulai dari harga Rp 500.000,- s/d Rp 1.000.000,- sementara $50 \%$ lainnya menginginkan harga handphone di atas Rp 1.000.000,- s/d Rp 2.000.000,--

\section{KESIMPULAN DAN SARAN}

\subsection{Kesimpulan}

Profil konsumen Zicoms yaitu jumlah responden laki - laki lebih banyak daripada jumlah responden perempuan. Selain itu, usia konsumen lebih dominan di atas 30 tahun serta pekerjaan yang dimiliki lebih banyak yang mempunyai jawaban tersendiri seperti ibu rumah tangga, pelaut, guru ataupun dosen. Untuk alamat yang dimiliki 53\% dari total seluruh responden beralamatkan di daerah Taman.

Dari 35 variabel berupa item pertanyaan, langkah selanjutnya memenuhi asumsi cluster untuk memilih variabel yang tepat dan dapat mewakili dari 35 variabel yang lainnya. Hasilnya terpilih 8 variabel untuk dapat mengikuti pengujian berikutnya. Selanjutnya mengelompokkan variabelvariabel dengan langkah-langkah analisis cluster. Terbentuk 4 cluster/kelompok yang masing- masing mempunyai karakteristik berbeda-beda yaitu:

Tabel 5.1 Karakteristik masing-masing cluster

\begin{tabular}{|l|l|l|}
\hline No & Cluster & \multicolumn{1}{c|}{ Karakteristik } \\
\hline 1 & Cluster 1 & $\begin{array}{l}\text { Termasuk kategori konsumen yang } \\
\text { telah menjadi pelanggan dan } \\
\text { konsumen kalangan menengah. }\end{array}$ \\
\hline 2 & Cluster 2 & $\begin{array}{l}\text { Termasuk kategori konsumen baru } \\
\text { dan konsumen } \\
\text { kalangan menengah }\end{array}$ \\
\hline 3 & Cluster 3 & $\begin{array}{l}\text { Termasuk kategori konsumen yang } \\
\text { telah menjadi } \\
\text { pelanggan dan konsumen kalangan ke } \\
\text { atas }\end{array}$ \\
\hline 4 & Cluster 4 & $\begin{array}{l}\text { Termasuk kategori konsumen baru } \\
\text { yang 100\% } \\
\text { responden baru berbelanja di toko } \\
\text { Zicoms dan konsumen kalangan } \\
\text { menengah }\end{array}$ \\
\hline
\end{tabular}


Strategi yang dapat dilakukan berdasarkan hasil dari analisis clustering adalah untuk cluster 1 yaitu memperbanyak stok handphone yang mempunyai desain bagus, tidak mudah rusak, kualitas baterai yang mampu bertahan $1 / 2$ hari atau 12 jam serta memperoleh bonus free kartu perdana, dengan kisaran harga mulai dari Rp 500.000,- s/d Rp 1.000.000,-. Untuk cluster 2 memperbanyak stok handphone yang mempunyai fitur lengkap, tidak mudah rusak, kualitas baterai yang mampu bertahan 1-2 hari serta memperoleh bonus free internet 1 tahun, dengan kisaran harga mulai dari Rp 500.000,s/d Rp 1.000.000,-. Untuk cluster 3 memperbanyak stok handphone yang mempunyai fitur lengkap, tidak mudah rusak, kualitas baterai yang mampu bertahan mulai dari $1 / 2$ hari, 1-2 hari dan lebih dari 2 hari serta memperoleh bonus free internet 1 tahun, dengan kisaran harga di atas Rp 2.000.000,-. Untuk cluster 4 memperbanyak stok handphone yang mempunyai fitur lengkap, aplikasi banyak, dapat memberikan manfaat dalam mencari informasi/ilmu yang dibutuhkan, kualitas baterai yang mampu bertahan 1-2 hari serta memperoleh bonus free baik kartu perdana ataupun assesoris, dengan kisaran harga mulai dari $\mathrm{Rp} 500.000,-$ s/d Rp 2.000.000,-

\subsection{Saran}

Dari hasil penelitian ini, maka beberapa saran yang dapat diberikan adalah:

1. Arahan yang dihasilkan dari penelitian ini dapat digunakan sebagai acuan untuk mengembangkan toko Zicoms di daerah Sepanjang khususnya dalam pengadaan barang dan promosi yang diberikan dalam penjualan handphone mengingat begitu banyak pesaing di daerah Sepanjang. Selain itu melihat dari strategi lokasi dari toko Zicoms diharapkan dapat menjadi salah satu toko penjualan handphone yang menjadi pilihan paling favorit bagi masyarakat di daerah Sepanjang.

2. Promosi yang dapat dilakukan di toko Zicoms adalah promo pembelian banyak item dan mendapatkan potongan harga, serta dalam rangka memperingati hari kemerdekaan, Zicoms dapat ikut berpartisipasi dengan mengadakan promo bertemakan "Merdeka dari Harga Mahal" dengan cara pemberian diskon besar-besaran dengan syarat dan ketentuan berlaku
Aaker, David A. 1997. Manajemen Ekuitas Merek: Memanfaatkan Nilai dari Suatu Merek. Cetakan Pertama. Jakarta: Mitra Utama.

Dharmesta, Basu Swastha dan Irawan. 2005. Manajemen Pemasaran Modern. Edisi Kedua. Yogyakarta: Liberty.

Dunne, Lusch, Griffith. 2002. Retaling (4th ed). New York : south-western, a division of thomsom learning

Fitzsimmons, James A., Mona J. Fitzsimmons. 2004. Service Management: Operation, Strategy and Information Technology, 4ed. New York : McGraw-Hill.

Foster, Bob. 2008 . Manajemen Ritel. Bandung : Alfabeta.

Hair, Jr., Joseph, F., Rolph E., Anderson, Ronald., L., Tatham and William C., Black. 1998. Multivariate Data Analysis 5th Edition. New Jersey : Prentice- Hall International Inc.

Johnson, R.A and Wichern, D W. 1992. Applied Multivariat Statistical Analysis.

New Jersey : Prentice Hall. Engle wood Cluffs. 2007. Applied Multivariate Statistical Analysis, Sixth Edition, New Jersey : Prentice Hall.

Julita. 2001. Menuju Kepuasan Pelanggan Melalui Penciptaan Kualitas Pelayanan. Dalam Jurnal Ilmiah Manajemen dan Bisnis Univ Muhammadiyah Sumut, Vol 01.

Kotler, P., \& Armstrong, G. 2001. Prinsip - Prinsip Pemasaran, edisi kedelapan, jilid 1. Jakarta: Erlangga.

Kotler, Philip. 2005. Manajemen Pemasaran. Edisi Kesebelas Jilid Dua. Jakarta: Indeks.

Peter, J Paul., and Olson., Jerry C,. 2000. Consumer Behavior: Perilaku Konsumen dan Strategi Pemasaran. Terjemahan Damos Sihombing. Jakarta: Jilid 1. Edisi 4, Erlangga.

Santoso, Singgih. 2010. Statistik Multivariat. Jakarta : PT Elex Media Komputindo.

Simamora, Bilson. 2005. Analisis Multivariat Pemasaran. Jakarta : Gramedia Pustaka Utama.

Siregar, Syofian. 2010. Statistika Deskriptif untuk Penelitian. Jakarta : RajaGrafindo Persada.

Sujarweni, Wiratna V dan Endrayanto, Poly. 2012. Statistika Untuk Penelitian. Yogyakarta: Graha Ilmu.

Sugiyono. 2002. Metode Penelitian Bisnis. Jakarta : Gramedia Pustaka Utama. Sugiyono, Prof. Dr. 2013. Statistika Untuk Penelitian. Bandung : Alfabeta.

\section{DAFTAR PUSTAKA}


Supranto, J. 2000. Teknik Sampling untuk Survei dan Eksperimen. Jakarta : Rineka Cipta. 2004. Analisis Multivariat Arti \& Interpretasi. Jakarta : Rineka Cipta. Suprapto, Prof. J. 2004. Analisis Multivariat, Arti \& Interpretasi. Jakarta : Rineka Cipta.

Stanton, W.J. dan L. Lamarto. 2001. Prinsip Pemasaran Jilid I. Jakarta : Erlangga.

Suhendar,A. 2009. Pengaruh Budaya Belajar Organisasi, Dukungan Manajemen, Daya Dukung Sarana, Dan Kualitas Pemanfaatan Internet Terhadap Kompetensi Guru http://asepsuhendar.wordpress.com/resum etesis/, diakses tanggal 27 Maret 2010.
Sumarwan, Ujang. 2004. Perilaku Konsumen. Bogor: Ghalia Indonesia. 